\title{
Intraspecific non-sexual interactions of Grammostola schulzei (Araneae: Theraphosidae) under laboratory conditions
}

\author{
Nelson E. Ferretti ${ }^{1}$ \& Fernando Pérez-Miles ${ }^{2}$ \\ 1. Centro de Estudios Parasitológicos y de Vectores CEPAVE (CCT-CONICET-La Plata) (UNLP), Calle $2 \mathrm{~N}^{\circ} 584$, \\ (1900) La Plata, Argentina; nferretti@conicet.gov.ar \\ 2. Facultad de Ciencias, Sección Entomología, Iguá 4225, (11400) Montevideo, Uruguay; myga@ fcien.com.uy
}

\author{
Received 13-IX-2010. C Corrected 20-I-2011. Accepted 15-II-2011.
}

\begin{abstract}
Intraspecific interactions of araneomorph spiders have received considerable attention, but there are few detailed studies on intraspecific interactions of mygalomorph spiders. Moreover, a thorough understanding of theraphosid biology and ecology is necessary from a conservation standpoint because natural populations may be threatened by habitat disturbances and captures for pet commerce. We described the behavior of conspecific individuals of Grammostola schulzei during non-sexual interactions, under laboratory conditions. Pairs of individuals involving adult males, adult females and juveniles were confronted and observed in resident and intruder conditions, totalizing 115 trials. When confronted two adult females, they retreated or grappled, and performed gaping display with bite attempts, usually resulted in severe injury of the intruder spiders. When confronted females with large juveniles, we frequently observed cannibalism on juveniles. Juveniles exposed to females or to other juveniles retreated or made leg tapping with forelegs and palpal drumming, which are common displays of courting adult males. Adult males courted and clasped some juveniles, but juveniles avoided or reject clasping. The behaviors observed during intraspecific interactions could play an important role determining spatial distribution and could lead to behavioral adaptations of territoriality. Rev. Biol. Trop. 59 (3): 1173-1182. Epub 2011 September 01.
\end{abstract}

Key words: Argentinean tarantulas, conspecific non-sexual interactions, behavior, territoriality.

Mygalomorphs spiders (theraphosids spider lineages in particular) possess life-history traits that differ markedly from other spiders. For example, some species live for 15-30 years and require 5-6 years to reach reproductive maturity (Main 1978, Vincent 1993). Most species are habitat specialists and are extraordinarily sedentary (Main 1987, Vincent 1993, Coyle \& Icenogle 1994). These life-history traits promote geographic fragmentation over space and time, resulting in a large number of taxa that have small geographic distributions. This combination of life-history characteristics such as longevity, habitat specialists with poor dispersal abilities and small geographic ranges, parallels general characteristics of taxa that are extinction prone, either at the population or species level (McKinney 1997, Purvis et al. 2000). Moreover, a thorough understanding of theraphosid biology and ecology is necessary from a conservation standpoint because natural populations may be threatened by habitat disturbances and captures for pet commerce (Costa \& Pérez-Miles 2002).

Intraspecific interactions of araneomorph spiders have received considerable attention, but there are few detailed studies on intraspecific interactions of mygalomorph spiders (Paz 1988, Jackson \& Pollard 1990, Pérez-Miles \& Costa 1992). This gap should be filled because, as Raven (1980) pointed out, mygalomorphs have many features that are plesiomorphic for 
spiders and this suggests that research on these spiders will provide important perspectives on evolutionary hypotheses. An increasing number of studies of reproductive behavior of mygalomorphs have revealed intricate mechanisms of communication employed by this group (Coyle 1986, Coyle \& O’Shields 1990, Jackson \& Pollard 1990, Costa \& Pérez-Miles 1998), and particularly on Theraphosidae (Baerg 1958, Minch 1979, Costa \& Pérez-Miles 1992, PérezMiles \& Costa 1992, Prentice 1992, 1997, Shillington \& Verrel 1997, Punzo \& Henderson 1999, Yánez et al. 1999, Costa \& Pérez-Miles 2002, Quirici \& Costa 2005). Theraphosids may be especially useful models on which to base evolutionary interpretations in biological studies (Costa \& Pérez-Miles 2002) and their phylogenetic systematics is reasonably wellknown (Pérez-Miles et al. 1996, Bertani 2000).

Theraphosids male courtship mainly consists in palpation, palpal drumming, body vibrations and leg tapping before contacting female (see Costa \& Pérez-Miles 2002 for a review), but little is known about the non-sexual intraspecific interactions. These last interactions might have an important role in determining the distribution of conspecific individuals (Yañez \& Floater 2000). Since theraphosid spiderlings have limited dispersal ability, an aggregated distribution is expected (Stradling 1994, Shilington \& McEwen 2006). Moreover, in diplurid mygalomorphs, this aggregated distribution might lead to behavioral adaptations to territoriality (Paz 1988). If theraphosids are prone to territoriality, then we might also predict that these spiders will adopt behavioral adaptations as intricate mechanisms of communication during non-sexual behavior.

Grammostola schulzei (Schmidt 1994) is a medium-sized Argentinean tarantula that inhabits burrows constructed under stones in the rocky hills of Northern and central Argentina (Ferretti \& Ferrero 2008). Adult males of the species would not have fixed home ranges, and move frequently in search of females. Adult females occupy soil burrows under stones and remain within or close to this shelter at all times. The female lays a single egg sac per year containing 100-400 eggs in her shelter in December (N.E. Ferretti pers. observ.), at the beginning of summer. The female guards the egg sac for two to three months until spiderlings emerge in February-March. Juveniles inhabit small burrows under stones, and large juveniles may remain in the same site during many years (Shilington \& McEwen 2006).

The aim of this study was to describe the non-sexual interactions among males, females and large juveniles of G. schulzei under laboratory conditions, for reaching a better understanding of the spatial distribution of these individuals.

\section{MATERIALS AND METHODS}

Spiders: All the individuals were collected during summer (from January to February in the Southern Hemisphere) of 2005 and 2006 , in Sierra de la Ventana ( $38^{\circ} 07^{\prime} 63^{\prime \prime} \mathrm{S}-61^{\circ}$ 47'30" W), Buenos Aires, Argentina. We located individuals on their burrows, under stones in rocky hill zones. Spiders were maintained individually in glass vials of $13 \mathrm{~cm}$ diameter or rectangular glass containers of $30 \times 14 \times 15 \mathrm{~cm}$ according to their size, with soil and water provision. All individuals were fed ad libitum with cockroaches (Blattela germanica) and Tenebrio sp. larvae (Coleoptera). For the trials we initially used five adult males, five adult females and five juveniles of G. schulzei. When spiders were injured or dead in the trials, new spiders of the same category were used. "Male" and "female" refer only to adult animals while "juveniles" refer to large immature individuals of unknown sex. All the females molted between December 2006 and January 2006 so they had no stored sperm. The observations were performed from January 2006 to April 2006 and from September 2006 to March 2007, during the activity period of this species (N.E. Ferretti, pers. observ.). Both carapace length and weight of females, males and juveniles were measured and expressed as mean \pm one standard deviation. Female carapace length averaged $21 \mathrm{~mm} \pm 3.1 \mathrm{SD}(\mathrm{n}=5)$ and weighed $8.95 \mathrm{~g} \pm 0.75 \mathrm{SD}(\mathrm{n}=5)$; male carapace length 
averaged $15.4 \mathrm{~mm} \pm 1.6 \mathrm{SD}(\mathrm{n}=5)$ and weight showed average $4.72 \mathrm{~g} \pm 0.82 \mathrm{SD}(\mathrm{n}=5)$; juveniles averaged $15 \mathrm{~mm} \pm 2.1 \mathrm{SD}(\mathrm{n}=5)$ of carapace length and weighed $3.96 \mathrm{~g} \pm 1.22 \mathrm{SD}(\mathrm{n}=5)$. The mean environmental temperature during the trials was $26.7^{\circ} \mathrm{C} \pm 1.52 \mathrm{SD} \quad(\mathrm{n}=115)$. Voucher specimens were deposited in the Entomological collection of Zoology of Invertebrates II, Universidad Nacional Del Sur, Buenos Aires, Argentina.

Experimental design: All the interactions between pairs resident-intruder took place in cages of $30 \times 35 \mathrm{~cm}$ base and $30 \mathrm{~cm}$ height, with soil as substrate. Individuals were randomly assigned to each pair. The resident spider (R) was placed $48 \mathrm{hr}$ before the trials to allow silk deposition on the substrate. Then, an intruder spider (I) was placed as far as possible from the position of the resident. Each particular pairing was not used again and each spider was reused after one week. Considering the pheromone deposition in spiders we removed the silk threads of substrate by removing the soil and spraying alcohol over the surface. We created the following experimental groups: Male (I) - Juvenile (R) (25 trials), Juvenile (I) - Female (R) (25 trials), Female (I) - Juvenile (R) (25 trials), Female - Female (20 trials) and Juvenile - Juvenile (20 trials), totalizing 115 trials. The pairs Male - Female were not used because the sexual behavior of this species was already described (Ferretti \& Ferrero 2008). In the Male - Juvenile pairs, males were only intruders due to the wandering characteristics of adult males. Male - Male pairs were not carried out due the same reason. On each experimental group, one individual was exposed to the other spiders (five spiders in the first three experimental groups and four spiders in the last two ones) in all possible combinations. Each individual was used five times in the first three experiments and four times in the last two ones. Observations started when the intruder spider touched the substrate and ended after $60 \mathrm{~min}$, after aggression between the individuals, or after three consecutive contacts with no reaction between the spiders.
Encounters were directly observed and most of them (90\%) were video recorded with a Handycam Panasonic SDR-S7. Video records were analyzed using slow motion and single frame advance modes with a PC program (Sony Vegas 9.0) in order to describe accurately the behavioral patterns by occurrence frequencies. Normality and homogeneity of variance was tested using the KolgomorovSmirnov and Levene tests. We used Chi-square tests to compare frequencies of occurrences and no-occurrence of each behavior between two samples. The Pearson (when variables where non parametric) and Spearman (with parametric variables) correlations were used to explore possible linear relations between the variables. Male courtship behavioral units mentioned in this work follow Ferretti \& Ferrero (2008). All statistical analyses were performed using SPSS statistical package, version 14.0 for Windows (2005).

\section{RESULTS}

Behaviors performed by females, juveniles and males in each experimental group are shown in Table 1, expressed as occurrence frequencies.

Female-female interactions: In three cases, intruder females made very rapid attacks "charges" by walking towards the other spider (mean speed $16.6 \mathrm{~cm}$ per second). In these cases, we observed an initial fast motion along the first $15.0 \mathrm{~cm}$ that then turned slower near the other spider $(1.08 \mathrm{~cm} / \mathrm{s})$. A single resident female made a "charge". After contact, we observed two types of responses. One of them was "retreat" of one or both individuals, separating each other by retreating walking slowly or turning away. There were no significant differences between retreats of residents and intruders spiders $\left(\chi^{2}=25.33, \mathrm{p}=0.06\right)$. The other response was "gaping display": a spider gaped chelicerae (with fangs extended or not) and raised the carapace, palps and usually forelegs (Fig. 1). We found no significant differences in the occurrence frequencies of gaping between residents and intruders $\left(\chi^{2}=13.56\right.$, 
TABLE 1

Occurrence frequencies of behaviors from males (intruder), females (intruder and resident) and juveniles (intruder and resident)

\begin{tabular}{|c|c|c|c|c|c|}
\hline & Males (I) & $\begin{array}{l}\text { Juveniles } \\
\text { (I and R) }\end{array}$ & $\begin{array}{c}\text { Juvenile- } \\
\text { Juvenile }\end{array}$ & Female-Female & $\begin{array}{l}\text { Females } \\
\text { (I and R) }\end{array}$ \\
\hline Number $^{1}$ & 25 & 25 & 20 & 20 & 25 \\
\hline Charge & 8 & 0 & 0 & 6 & 11 \\
\hline Retreat & 6 & 68 & 56 & 38 & 26 \\
\hline Bite or kill other spider & 0 & 13 & 5 & 4 & 11 \\
\hline Lay down silk & 2 & 5 & 6 & 16 & 6 \\
\hline Body vibration & 4 & 0 & 0 & 0 & 0 \\
\hline Palpal drumming & 39 & 0 & 0 & 0 & 0 \\
\hline Spasmodic beats & 61 & 0 & 0 & 0 & 0 \\
\hline Leg tapping & 21 & 0 & 0 & 0 & 0 \\
\hline Gaping display & 6 & 9 & 4 & 27 & 3 \\
\hline Clasping & 20 & 0 & 0 & 0 & 0 \\
\hline Leg tapping and palpal drumming & 0 & 17 & 15 & 0 & 12 \\
\hline Swing & 0 & 0 & 0 & 18 & 0 \\
\hline
\end{tabular}

1. I: intruder. R: resident.

2. Total number of encounters.

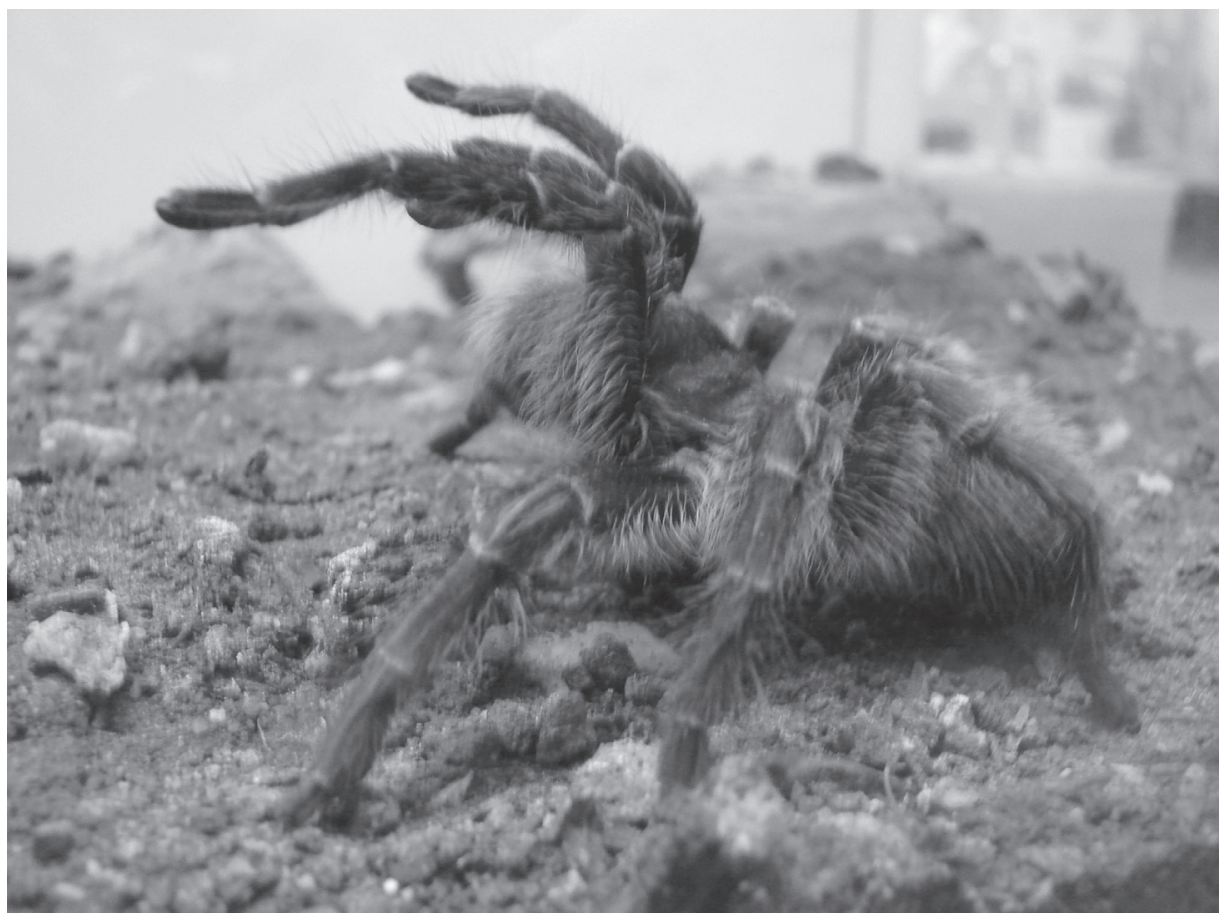

Fig. 1. Female of Grammostola schulzei displaying gaping, lateral view. Note carapace, palps and forelegs raised, cheliceral fangs closed and the other legs forming a wide base of sustentation. 
$\mathrm{p}=0.19$ ). We found statistically significant differences between correlations of weight and carapace length with "gaping display" of resident females and with "retreats" of intruder females (Table 2).

Other observed behavior was "grappling", in which both spiders positioned face-to-face, interlacing the extended first and second pair of legs, and moving them quickly and irregularly. Palps were maintained raised and fangs extended (Fig. 2). Four intruders were injured on forelegs and one was killed. Six females retreated safely. Females that did not retreat displayed gaping during some minutes and performed "swinging". This behavior consisted of body oscillations (forward and backward movements) maintaining the carapace raised as well as the first and second legs. We observed 13 bouts swinging performed by
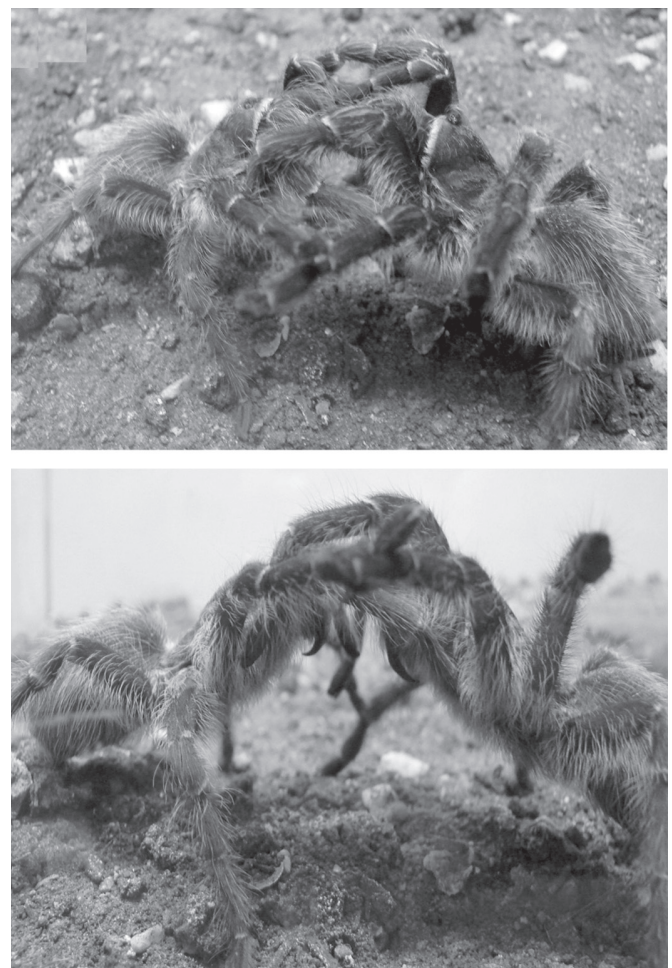

Fig. 2. Left: Two females performing grappling and pushing (legs III and IV stand the soil), lateral view. Right: Next aggressive step, where females opened their fangs and make bite attempts. 
resident females and five by intruder females during all encounters. The "release of draglines" by intruder females was frequent before retreating or confronting (16 bouts in all interactions). Each female oscillated side to side the abdomen, laying silken threads on the substrate while often walked slowly.

Female-juvenile interactions: Eight resident females performed "charge" towards the juveniles, while two females performed it as intruders. Occurrences frequencies of retreat were greater in intruder females than resident females $\left(\chi^{2}=14.5, p<0.001\right)$. Eight resident females killed juveniles by biting the abdomen and carapace. The intruder females did not display "gaping" but they laid down silk. Only intruder females performed leg tapping and palpal drumming. Leg tapping involved both forelegs simultaneously or alternately, involving leg raising, extension and an abrupt downward movement hitting the soil. Leg tapping was always followed by palpal drumming, where both palps tapped alternately the substrate. These behaviors were considered as a single behavior "tapping/drumming", showing a mean duration of 5.20 seconds $( \pm 1.93$, $\mathrm{n}=10$ ). We found statistically significant differences between correlations of weight and carapace length with "retreats" and "bites or kills" of resident females (Table 2). Female "retreats" after contact were determined by the weight and size of both individuals and the smaller females did not "grapple" with juveniles of similar size.

Juveniles did not perform "charge" towards females in any case. The more frequent behavior was "retreat" (42 bouts during all encounters). The occurrence frequencies of retreat were higher in resident than intruder juveniles $\left(\chi^{2}=4, p<0.001\right)$. We found no significant differences between correlations of retreats with weight and carapace length (Table 2). Only juveniles displayed "gaping" and "bite attempt" in response to female attacks. Intruder juveniles showed higher occurrence frequencies of "tapping/drumming" (17 bouts) when compared to resident juveniles (only one bout) using Chi-square two sample test $\left(\chi^{2}=24, p<0.001\right)$.

Juvenile-juvenile interactions: Juvenile intruders made 21 bouts of "tapping/drumming" and only one juvenile resident performed it. We found significant differences in the occurrence frequencies of "tapping/drumming" between resident and intruder $\left(\chi^{2}=29\right.$, $\mathrm{p}<0.001)$. Four juveniles displayed "gaping" and grappled with other juveniles. We observed two "gaping displays" from juvenile residents and two from juvenile intruders. Residents and intruders showed the same occurrence frequencies of "retreat" $\left(\chi^{2}=5.47, p=0.94\right)$. We found no significant differences between correlations of retreats with weight and carapace length (Table 2).

Male-juvenile interactions: Males made "charge" eight times towards juveniles and retreated in six cases. Before contacting, males performed "palpal drumming" far away from the juvenile location, as well as "leg tapping" and "body vibrations" caused by contractions of the third pair of legs. After contacting, five males made "spasmodic beats" on the body of juveniles with the second pair of legs, alternated or synchronously. These males "clasped" the juvenile's fangs with the tibial apophyses of forelegs, and raised the juvenile carapace by extending forelegs and pushing it. One male tried to make a palpal insertion by extending a palp towards the epigastric zone of the juvenile, while the other palp remained semi-extended. All juveniles tried to escape from clasping. In six cases males displayed "gaping". After contacting with males, juveniles mainly performed "retreat" (Table 1). Juveniles performed 27 retreats, nine gaping displays and one bout of "tapping/drumming". No cases of biting or cannibalism were observed.

\section{DISCUSSION}

Usually, intraspecific interactions of mygalomorph spiders in captivity (mainly during mating behavior) probably do not differ from 
the behaviors observed in the wild (Jackson 1988, Jackson \& Pollard 1990, Bertani et al. 2008, Ferretti \& Ferrerro 2008) and it seems likely that our observations in captivity are representative of $G$. schulzei behavior. The agonistic behavior including offensive and defensive ones predominated during this study, as expected in predatory and cannibalistic animals as the spiders. Moreover, these behaviors could be acting as ritualized ones, thus determining the spatial distribution and protecting their burrows and shelters on nature.

Female-female interactions: Before the "grapples", small intruder females tend to make "retreat" than large ones. Unexpectedly, intruder females made more "charges" than residents. Contrarily, Paz (1988) observed that intruder spiders of the diplurid Linothele sp. always retreated. These "charges" from intruder females could be a tactic to displace resident spiders and occupy limited shelters open areas. As expected, once in contact the predominance of resident females would depend of their weight and carapace length measures because we found a positive correlation of these variables with the gaping display made by resident females towards intruders, so larger females tend to be more aggressive than smaller females. Pérez-Miles \& Costa (1992) observed in Grammostola mollicoma (Ausserer 1875) that weight determined the predominance and that mutual estimation of females was made by performing ritualized fights, which could involve also bites, pushes and resistance. We found one case of cannibalism and several injuries between the females, which were considered uncommon for Theraphosidae (Costa \& Pérez-Miles 2002). Moreover, in G. mollicoma, the grapple pattern, scarcity of injuries and the inhibition of attacks in non-frontal position suggest that this species is territorial but can live in an aggregated distribution (Pérez-Miles \& Costa 1992).

In nature the encounters between females of $G$. schulzei could be more frequent than expected; for example, in the territorial boundaries because these Theraphosids are sedentary and also when some spiders abandon sites with scarce resources. In Brachypelma vagans Ausserer 1875, females were attracted for the cues left by other conspecific females, leading to aggressive interactions between them (Dor et al. 2008). Resident G. schulzei spiders also were very aggressive towards the intruders, in agreement to the observations of Paz (1988) in Linothele sp. (Dipluridae), as a clear tactic for both protecting burrows and foraging opportunities. The "gaping display" could be a threatening display, persuading conspecific spiders against dangerous aggressive encounters and also positioning the spider for easily attack or defend. Jackson \& Pollard (1990) proposed an antipredator defense function for "gaping display" in the hexathelid Porrothele antipodiana (Walckenaer 1837). This behavior could be also displayed towards any large animal perceived as a potential predator. "Gaping display" is widespread in Theraphosidae, and is performed when tarantulas are disturbed in open areas where burrows and refuges are scarce (Pérez-Miles et al. 2005). The "swinging" display, where G. schulzei spiders perform forward and backward movements with the first and second pair of legs, is described here for the first time for therpaphosid spiders. Acanthoscurria suina Pocock, 1903 also makes vigorous forward and backward movements, but involving only the first pair of legs (PérezMiles et al. 2005). This behavior could act as an intimidating display more perceptible than gaping due to the oscillating movements, precluding an attack because female only needs to move down the carapace to bite the opponent.

Female-juvenile interactions: Female "retreats" after contact were determined by the weight and size of both individuals. The smaller females did not "grapple" with juveniles of similar size and the frequent cannibalism of females on juveniles was correlated with juvenile size but not with their weight. Considering that the size is also positively related with "gaping display", larger females usually started the grapple towards juveniles. Smaller juveniles could not offer an effective resistance 
and frequently were subdued. However, some juveniles performed "gaping display" when confronted with females, contrarily to that observed by Jackson \& Pollard (1990) in Porrothele antipodiana. Juveniles also displayed "tapping/drumming", which could work as an intimidating or inhibiting mechanism to prevent further female attacks. Moreover, "leg tapping" and "palpal drumming" also constitute common displays during male courtship, minimizing non-sexual responses from females (Jackson \& Pollard 1990, Costa \& Pérez-Miles 2002, Ferretti \& Ferrero 2008).

Female-juvenile encounters maybe frequent during juvenile dispersion, allowing cannibalism. The juveniles of Brachypelma klaasi are capable of travelling not more than 3 or $5 \mathrm{~m}$ away from their burrow searching for food or shelters (Yañez \& Floater 2000). In Hadronyche sp. (Hexathelidae) individuals can travel exceptionally distances of $23 \mathrm{~m}$ while searching for unoccupied shelters (Woodman et al. 2006). Juveniles also would contact with other juveniles and females when they establish their refuges and emerge for prey capture.

Juvenile-juvenile and male-juvenile interactions: The behavioral units of courtship of males observed during this study were similar to that reported by Ferretti \& Ferrero (2008) in sexual interactions for this species. The juveniles "clasped" by males remained active and tried to escape or bite, as was described by Jackson \& Pollard (1990) in the hexathelid $P$. antipodiana. These facts suggest a connection between sexual and agonistic behavior (PérezMiles \& Costa 1992). The clasping and mating attempts from males to conspecific other than adult females had already been reported by Pérez-Miles \& Costa (1992) for G. mollicoma in male-male encounters.

Most mygalomorph spiders are habitat specialists and females and juveniles are sedentary (Main 1987, Coyle \& Icenogle 1994). The limited dispersal ability of theraphosid juveniles (Shillington \& McEwen 2006) result into aggregation of individuals that could lead to behavioral adaptations for territoriality. The habitat occupied by G. schulzei comprises hilly zones where they build the burrows, but burrow dimensions are always limited by the heavy stony substrate (N.E. Ferretti, pers. observ.). Juveniles and females need to find new shelters according to their size. Hence, the behaviors observed in this study during intraspecific interactions could play an important role by limiting density due to the scarcity of adequate sites for refuge construction. This intense competition could be less intense in species that dig and inhabit burrows in meadows, where females and juveniles dispose of many adequate sites (Main 1987).

\section{ACKNOWLEDGMENTS}

Thanks to Anita Aisenberg for the valuable comments on this manuscript and to improve English. Thanks also to the anonymous reviewers for improving the manuscript. Daniela Soresi, Gabriel Pompozzi and Sofía Copperi helped us collect the specimens. We are also grateful to Gabriel Pompozzi for his valuable help with the experiments. We are thanking all lab partners for helping us rear the tarantulas: Adriana Ferrero, Mercedes Gutiérrez, Natalia Stefanazzi, Carolina Sanchez Chopa, Verónica Benzi and Jorge Werdin. The Laboratory of Invertebrates Zoology II, Universidad Nacional del Sur, provided facilities. N. F. is supported by a CONICET fellowship.

\section{RESUMEN}

Hay pocos estudios detallados sobre las interacciones intraespecíficas de arañas migalomorfas. Por lo tanto, se describe el comportamiento de individuos conspecíficos de Grammostola schulzei durante interacciones nosexuales en condiciones de laboratorio. Se confrontaron y observaron pares de individuos involucrando machos adultos, hembras adultas y juveniles en condiciones de locatarios y visitantes, totalizando 115 encuentros. Cuando dos hembras adultas se enfrentaron, retrocedieron o lucharon adoptando elevaciones anteriores e intentos de mordeduras que usualmente resultaron en arañas visitantes heridas. Cuando se enfrentaron hembras con juveniles, frecuentemente se observó canibalismo sobre los juveniles. Los juveniles expuestos a otros juveniles o hembras retrocedieron o realizaron golpes con patas delanteras y 
tamborileos de palpos, los cuales constituyen unidades de comportamiento comunes durante el cortejo de los machos. Los machos adultos cortejaron y trabaron a algunos juveniles, mientras que los juveniles los evitaron o rechazaron el enganche. Los comportamientos observados durante las interacciones intraespecíficas podrían jugar un papel importante en la distribución espacial y podrían generar adaptaciones al territorialismo.

Palabras clave: tarántulas argentinas, interacciones coespecíficas, comportamiento, territorialismo.

\section{REFERENCES}

Baerg, W.J. 1958. The Tarantula. Lawerence, University of Kansas, Kansas, USA.

Bertani, R. 2000. Male palpal bulbs and homologous features in Theraphosinae (Araneae, Theraphosidae). J. Arachnol. 28: 29-42.

Bertani, R., C.S. Fukushima \& P.I. Silva Jr. 2008. Mating behavior of Sickius longibulbi (Araneae, Theraphosidae, Ischnocolinae), a spider that lacks spermathecae. J. Arachnol. 36: 331-335.

Costa, F.G. \& F. Pérez-Miles. 1992. Notes on mating and reproductive success of Ceropelma longisternalis (Araneae, Theraphosidae) in captivity. J. Arachnol. 20: $129-133$

Costa, F.G. \& F. Pérez-Miles. 1998. Behavior, life cycle and webs of Mecicobothrium thorelli (Araneae, Mygalomorphae, Mecicobothriidae). J. Arachnol. 26: 317-329.

Costa, F.G. \& F. Pérez-Miles. 2002. Reproductive biology of Uruguayan theraphosids (Araneae, Theraphosidae). J. Arachnol. 30: 571-587.

Coyle, F.A. 1986. Courtship, mating, and the function of male-specific structures in the mygalomorph spider genus Euagrus (Araneae, Dipluridae), p. 33-38. In W.G. Eberhard, Y.D. Lubin \& B.C. Robinson (eds.). Proc. Ninth Int. Congr. Arachnology, Panama. Smithsonian Institution, Washington, D.C., USA.

Coyle, F.A. \& T.C. O’Shields. 1990. Courtship and mating behavior of Telochoris karschi (Araneae, Dipluridae), an African funnel web spider. J. Arachnol. 18: 281-296.

Coyle, F.A. \& W.R. Icenogle. 1994. Natural history of the California trapdoor spider genus Aliatypus (Araneae, Antrodiaetidae). J. Arachnol. 22: 225-255

Dor, A., S. Machkour-M’Rabet, L. Legal, T. Williams \& Y. Hénaut. 2008. Chemically mediated burrow recognition in the Mexican tarantula Brachypelma vagans female. Naturwissenschaften 95: 1189-1193.

Ferretti, N. \& A. Ferrero. 2008. Courtship and mating behavior of Grammostola schulzei (Schmidt 1994) a burrowing tarantula from Argentina. J. Arachnol. 36: $480-483$.

Jackson, R.R. 1988. The biology of Jacksonoides quensladicus, a jumping spider (Araneae: Salticidae) from Queensland: intraspecific interactions, web-invasion, predators, and prey. New Zeal. J. Zool. 15: 1-37.

Jackson, R.R. \& S.D. Pollard. 1990. Intraspecific interactions and the function of courtship in mygalomorph spiders: a study of Porrothele antipodiana (Araneae, Hexathelidae) and a literature review. New Zeal. J. Zool. 17: 499-526.

Main, B.Y. 1978. Biology of the arid-adapted Australian trapdoor spider Anidiops villosus (rainbow). Bull. British Arachnol. Soc. 4: 161-175.

Main, B.Y. 1987. Ecological disturbance and conservation of spiders: implications for biogeographic relics in southwestern Australia, p. 89-98. In J.D. Majer (ed.). The role of invertebrates in conservation and biological survey. Western Australian Department of Conservation and Land Management Report, Perth, Australia.

McKinney, M.L. 1997. Extinction vulnerability and selectivity: combining ecological and paleontological views. Annu. Rev. Ecol. Syst. 28: 495-516.

Minch, E.W. 1979. Reproductive behaviour of the tarantula Aphonopelma chalcodes Chamberlin (Araneae, Theraphosidae). Bull. British Arachnol. Soc. 4: 416-420.

Paz, N. 1988. Ecología y aspectos del comportamiento de Linothele sp. (Araneae, Dipluridae). J. Arachnol. 16: 5-22.

Pérez-Miles, F. \& F.G. Costa. 1992. Interacciones intra e intersexuales en Grammostola mollicoma (Araneae, Theraphosidae) en condiciones experimentales. Bol. Soc. Zool. Uruguay 7: 71-72.

Pérez-Miles, F., S.M. Lucas, P. Da Silva \& R. Bertani. 1996. Systematic revision and cladistic analysis of Theraphosinae (Araneae, Theraphosidae). Mygalomorph 1: 33-68.

Pérez-Miles, F., F.G. Costa, C. Toscano-Gadea \& A. Mignone. 2005. Ecology and behaviour of the "road tarantulas" Eupalaestrus weijenberghi and Acanthoscurria suina (Araneae, Theraphosidae) from Uruguay. J. Nat. Hist. 39: 483-498. 
Prentice, T.R. 1992. A new species of North American tarantula, Aphonopelma paloma (Araneae, Mygalomorphae, Theraphosidae). J. Arachnol. 20: 189-199.

Prentice, T.R. 1997. Theraphosidae of the Mojave Desert west and north of the Colorado River (Araneae, Mygalomorphae, Theraphosidae). J. Arachnol. 25: $137-176$.

Punzo, F. \& L. Henderson. 1999. Aspects of the natural history and behavioural ecology of the tarantula spider Aphonopelma hentzi (Girard, 1854) (Orthognata, Theraphosidae). Bull. British Arachnol. Soc. 11: 121-128.Purvis, A., K.E. Jones \& G.M. Mace. 2000. Extinction. BioEssays 22: 1123-1133.

Quirici, V. \& F.G. Costa. 2005. Seismic communication during courtship in two burrowing tarantula spiders: an experimental study on Eupalaestrus weijenberghi and Acanthoscurria suina. J. Arachnol. 33: 199-208.

Raven, R.J. 1980. The evolution and biogeography of the mygalomorph spider family Hexathelidae (Araneae, Chelicerata). J. Arachnol. 8: 251-266.

Shillington, C. \& P. Verrell. 1997. Sexual strategies of a North American "Tarantula" (Araneae, Theraphosidae). Ethology 103: 588-598.
Shillington, C. \& B. McEwen. 2006. Activity of juvenile tarantulas in and around the maternal burrow. J. Arachnol. 34: 261-265.

SPSS. 2005. SPSS Base 14.0 for Windows user's guide. SPSS Inc. Chicago Illinois, USA.

Stradling, D.J. 1994. Distribution and behavioral ecology of an arboreal 'tarantula' spider in Trinidad. Biotropica. 26: 84-97.

Vincent, L.S. 1993. The natural history of the California turret spider Atypoides riversi (Araneae, Antrodiaetidae): demographics, growth rates, survivorship, and longevity. J. Arachnol. 21: 29-39.

Woodman, J.D., J.E. Ash \& D.M. Rowell. 2006. Population structure in a saproxylic funnelweb spider (Hexathelidae: Hadronyche) along a forested rainfall gradient. J. Zool. 268: 325-333.

Yañez, M., A. Locht \& R. Macías-Ordóñez. 1999. Courtship and mating behavior of Brachypelma klassi (Araneae, Theraphosidae). J. Arachnol. 27: 165-170.

Yañez, M. \& G. Floater. 2000. Spatial distribution and habitat preference of the endangered tarantula, $\mathrm{Bra}$ chypelma klaasi (Araneae: Theraphosidae) in Mexico. Biodivers. Conserv. 9: 795-810. 